\title{
Therapeutic Guitar-An Alternative Approach To the Treatment of a Difficult Patient
}

\author{
Michael Buxbaum, MD \\ Thomas Jefferson University Hospital
}

Follow this and additional works at: https://jdc.jefferson.edu/jeffjpsychiatry

Part of the Psychiatry Commons

Let us know how access to this document benefits you

\section{Recommended Citation}

Buxbaum, MD, Michael (1984) "Therapeutic Guitar-An Alternative Approach To the Treatment of a Difficult Patient," Jefferson Journal of Psychiatry. Vol. 2 : Iss. 1 , Article 11.

DOI: https://doi.org/10.29046/JJP.002.1.007

Available at: https://jdc.jefferson.edu/jeffjpsychiatry/vol2/iss1/11

This Article is brought to you for free and open access by the Jefferson Digital Commons. The Jefferson Digital Commons is a service of Thomas Jefferson University's Center for Teaching and Learning (CTL). The Commons is a showcase for Jefferson books and journals, peer-reviewed scholarly publications, unique historical collections from the University archives, and teaching tools. The Jefferson Digital Commons allows researchers and interested readers anywhere in the world to learn about and keep up to date with Jefferson scholarship. This article has been accepted for inclusion in Jefferson Journal of Psychiatry by an authorized administrator of the Jefferson Digital Commons. For more information, please contact: JeffersonDigitalCommons@jefferson.edu. 


\title{
THERAPEUTIC GUITAR-AN ALTERNATIVE APPROACH TO THE TREATMENT OF A DIFFICULT PATIENT
}

\author{
MICHAEL BUXBAUM, M.D.
}

The case described in this article is one where an experimental technique was introduced largely because of the therapist's dissatisfaction with the patient's progress. Despite the likelihood of being criticized, I feel compelled to write about this patient. The progress he has made is beyond my expectations, which were admittedly minimal at the outset.

The patient, a 24 year-old married white male with two children, was referred to the care of this writer in July of 1982 after his previous therapist left the clinic. When contacted, he stated that he felt that he did not need therapy. Less than four weeks later, he called for an appointment. During the initial interview, he said that he had been disappointed by his previous therapist who had had to leave him. He feared that this would occur once again if he resumed therapy with another resident. He was, however, having difficulties, although he had been able to continue functioning at work in his position as a bank teller, a job he had held for five years.

The patient's chief complaint initially was depression. The episodes were usually triggered by external events, lasted one to two days, and occurred at least once weekly. They were characterized by feelings of worthlessness, inferiority and hopelessness. His energy level was markedly decreased. The patient's appetite was good. He had, in fact, gained ten pounds over the preceding year. He had no sleep disturbance. In between episodes, he functioned well. There were no bipolar symptoms.

The patient's family history reveals that his father had an affective disorder for which he saw a psychiatrist for several years and was medicated with lithium. His sister is a schizophrenic, currently attending a day program and treated with intramuscular prolixin.

The patient's depression first manifested itself in January of 1979. At that time, the patient described feelings of inadequacy. He did not feel fit to carry out the roles he had assumed as husband and provider: "My mother always did everything for me." $\mathrm{He}$ consulted a psychiatrist in his neighborhood (who had also treated his father), and was treated with several medications in addition to supportive psychotherapy. He took lithium $300 \mathrm{mg}$ bid continuously from 1979 until he was seen at Jefferson. Only one level had been done which was $0.5 \mathrm{mEq} / 1$. Ascendin was added for several months beginning in December of 1980 . He also took very small amounts of Tofranil for short periods of time on two occasions.

The patient came to Jefferson for the first time in March of 1982 . He sought to change therapists because he was concerned that his neighbors "thought I was crazy

Dr. Buxbaum is a fourth-year resident in Psychiatry. 
for seeing a psychiatrist." The patient was reluctant to increase his daily dosage of lithuim to achieve a therapeutic blood level. He not only feared the side effects of the drug, but it seemed that in his mind, more medicine was tantamount to admitting the severity of his illness. Because the therapist was doubtful that lithium was truly indicated in this case, he did not press the issue and it was discontinued.

On mental status examination during the initial interview with this writer, the patient was a very handsome, well-dressed male. His affect was anxious, but he was able to show a full range of emotions. His mood was dysphoric. He was not psychomotor retarded. He was not psychotic or suicidal. The physical examination was within normal limits.

The patient was begun in insight-oriented psychotherapy without medication. Because he felt he neither could afford nor did he require weekly therapy, it was agreed that he would be seen every other week. It appeared that he viewed weekly sessions as he had regarded increasing the dosage of lithium; that is to say, more frequent sessions were synonymous with more severe psychopathology.

It soon became apparent that the events which triggered the patient's dysphoric episodes were of similar nature. When he perceived that authority figures were criticizing him, he would often feel inferior and unworthy. He wondered why people would have anything to do with him. These authority figures were, at various times, his bosses, his wife, friends (of which he had few), and, of course, his therapist. During the course of therapy it became clear that these authority figures represented, in particular, his father who was very critical of the patient. The roots of this patient's hypersensitivity to criticism were found, too, in the patient's vivid memories of being derided for his poor English and for his mannerisms which were native to Italy and often unfamiliar to Philadelphians.

The patient remembered his father as being very distant, unemotional, and extremely critical of his son. He was often impulsive and unpredictable. He would fly to Italy for long periods of time with little prior notice leaving his family behind. It is of note that this patient expressed anger at being abandoned by his previous therapist and was concerned that this might occur again with his replacement.

In treatment, this patient was very passive, overly pleasant and always reliable yet complained constantly that he felt no better. He would confirm the therapist's interpretations with little additional comment. He refused to increase the frequency of the sessions to weekly stating that he could not afford the fee yet insisted on paying cash and foregoing his insurance benefits for fear that it would be known that he had a psychiatric illness.

In the transference the therapist represented an authority figure (the patient's father) who often outwitted him and whose interpretations he had to accept for fear of rejection. One wonders if beneath this outward acquiescence, the patient was not unconsciously outraged at this therapist thus contributing to his dysphoric mood. He could not understand why a successful physician (therapist) would bother with an inadequate specimen like himself. Although these issues were addressed, the patient failed to make any progress.

A crisis which subsequently changed the course of therapy developed in May of 
1983. His wife began working for Avon and became quite successful. This reaffirmed his poor self image. The patient stated "Even a woman can do better than me." $\mathrm{He}$ began having suicidal thoughts and decreased appetite with some weight loss. No interpretation or other therapeutic intervention seemed to help. Partly in countertransference, but also based on patient's symptoms of biologic depression, he was begun on desipramine gradually increasing the dose to $150 \mathrm{mg}$ per day. He began to feel more energetic. His insomnia and anorexia improved. However, as one might predict, he constantly worried about possible side effects of the medication, calling the therapist frequently despite reassurance and adequate information. He also feared that others would think poorly of him if they knew that he required psychotropic medication.

The patient appeared to have a very weak ego structure further compromised by a harsh punitive superego. This superego might represent on some level the negativistic, punitive and unreliable father introject. Perhaps interpretations were unsuccessful with this patient because he was unable to see the therapist as someone who could help him understand himself. Rather the patient appeared to perceive the therapist as some magical figure who was treating him for reasons which were not readily apparent, and who simultaneously inspired both fear and admiration. The therapist represented his fantasy father image in whose presence he felt constantly under pressure. This patient also displayed impaired reality testing exemplified by suspiciousness bordering on paranoia.

One of my supervisors recalled a patient with similar pathology whom, after lack of progress in insight-oriented psychotherapy, he asked to teach him Spanish. This patient did remarkably well. Where he had been an unemployed high school graduate, he was able to obtain a college degree from a local university and go on to become a lawyer. My patient had an excellent knowledge of the guitar. When I approached him about giving me lessions, he immediately suspected my motives. He was unable to understand why I should go to such great lengths to help him and did not believe that I was truly interested in learning to play the guitar. Despite the patient's doubts he agreed to this method. He would see me weekly, alternating psychotherapy with lessons for which he would be paid $\$ 10.00,50 \%$ of his therapy fee.

These sessions began in June of 1983 and continue to the present. In these lessons, the therapist is the student and the patient the teacher. The patient quickly recognized how poor a student I was, and that I had little talent. During the first lesson, he remained passive, but as he recognized my shortcomings he became more active. He criticizes my poor performance and the fact that I do not practice as often as he recommends. He obviously gets pleasure when I swear in frustration after hitting a wrong note and when I am in pain from unaccustomed fingers pressing against the steel strings. He tells me how poorly I compare with other students he has taught. During these sessions I do not at all address therapy issues.

After the first few sessions, the patient was showing remarkable progress. He felt better than he had in years and appeared more optimistic and self-confident. His reality testing had also improved; he was not bothered as much by what others might think of him. In the therapy sessions, he became more active, sometimes challenging 
my statements. Where he had worked for five years as a bank teller without promotion, he began attending night classes at a local business school subsidized by the bank if he maintains a B average.

This patient's improvement is, I feel, due to his seeing me as a real person with whom he must learn to deal rather than the all-powerful, unpredictable, father-like fantasy image with whom he cannot cope. I have, in fact, become as he was in therapy - powerless, unable to learn, and making inexcusable mistakes. The fantasy father has fallen from the pedestal and the superego can relax.

In conclusion, this method of treatment has significant applications and can be successful in certain patients. Traditional psychotherapy is, of course, the initial starting point, but if it is a failure, as it was in this case, this type of therapy may be considered as an alternative. 